\title{
Russophobia, Free Trade and Maritime Insecurity
}

\author{
Unfortunately, no parties here in the Danube have any direct inter- \\ est in clearing the bar or facilitating the navigation; or if they have, \\ they have no direct influence with the Russian authorities. \\ Vice-Consul ST VINCENT LLOYD, 1853
}

By the summer of 1853 the ominous prediction of David Urquhart seemed to finally come true. For about two decades this 'knight-errant of justice and liberty'l or rather frantic and megalomaniac Scottish publicist had been warning the British public against Russia's imperial ambitions. With Russian troops marching into the Principalities, it was high time for Britain's political leadership to acknowledge the threat, and hopefully defend European civilisation along its ultimate frontier - the Lower Danube.

Russia's control of the Danube Delta had been one of Urquhart's leitmotifs in fleshing out the Russian menace. In distant and thinly-populated oozing marshes, Russia concocted ingenious plans to subdue the world. With his flair for conspiracies, Urquhart had sensed the danger and fought against it with his strongest weapon: his pen. The Scotsman was extremely prolific in publishing anti-Russian texts, and his radical views had been so popular since the $1830 \mathrm{~s}$ that he, more than any other author, is credited with shaping the character and tone of British Russophobia. ${ }^{2}$ His contribution to the genesis and dissemination of stereotypes on Russia has often been reviewed by historians, who have, however, focussed their narratives on other of Urquhart's favourite 'targets'. As

1 Gertrude Robinson, David Urquhart, Some Chapters in the Life of a Victorian Knight-Errant of Justice and Liberty (Oxford 1920).

2 John Howse Gleason, The Genesis of Russophobia in Great Britain 1815-1841 (Cambridge MA 1950), 286. 
the main narrative voice of this chapter, Urquhart will guide readers through the tortuous waters of the Maritime Danube and the area's commercial uncertainty in pre-Crimean War times. Switching between the first and the third analytical layers, i.e. between international politics and the many threats of Danubian swamps, I will discuss this little-known episode of the Eastern Question, born with the coming of capitalism to the Black Sea area and nourished by Russia's failure to govern one of its peripheral territories. Insecurity, which had an important economic dimension, ${ }^{3}$ was epitomised by the little town of Sulina, where a tight community of transnational 'bandits' earned huge profits by taking advantage of local natural hindrances, when not purposely supplementing them with artificial ones. The rather detailed description of these hazards and of the state of anarchy in which local commercial circles conducted their business are intended to explain the victors' decision to establish the European Commission of the Danube in 1856 .

Urquhart closely followed southeast European political and economic developments from the beginning of his public career. This started in 1833, when he published his first book, Turkey and Its Resources. Timing was perfect for his remarkable endeavour: the conclusion of the Russian-Ottoman Treaty of Hünkâr İskelessi (8 July 1833) had placed the Eastern Question high on Europe's diplomatic agenda. A war scare followed in the mid-183os and a cold war dragged Britain and Russia further apart, while making the Ottoman Empire a vital component of Europe's security structure. With his well-timed publication, Urquhart became an authority in the pioneering field of what can now be termed 'Ottoman area studies'. ${ }^{4}$ His expertise was, nevertheless, deeply biased by his ideological beliefs and political opinions.

In the following couple of years Urquhart restlessly toured southeastern Europe and the Black Sea area in a state-sponsored mission aiming to encourage British commercial ventures in a little explored periphery of the Ottoman lands. He also got into closer contact with John Ponsonby, British Ambassador to the Sublime Porte since 1833. Urquhart's cooperation with the Foreign Office

3 For the role of economic insecurities in building a European security culture see Glenda Sluga, 'Economic Insecurity, "Securities" and a European Security Culture after the Napoleonic Wars,' in: Beatrice de Graaf, Ido de Haan and Brian Vick (eds.), Securing Europe after Napoleon. 1815 and the New European Security Culture (Cambridge 2019), 288-305.

4 Margaret Lamb, 'The Making of a Russophobe: David Urquhart: The Formative Years, 18251835,' International History Review 3 (1981): 351. This part is an abbreviation of a larger article, published in Constantin Ardeleanu, 'The Danube Navigation in the Making of David Urquhart's Russophobia (1833-1837), Transylvanian Review 19 (2010), sup. 5: 337-352; the entire context is presented in Ardeleanu, International Trade and Diplomacy at the Lower Danube. The Sulina Question and the Economic Premises of the Crimean War (1829-1853) (Brăila 2014). 
and the Board of Trade was formalised in September 1835, when he was appointed secretary of the British Embassy to Istanbul.

Given his radical views, Urquhart was hardly qualified for diplomatic service. In his public appearances he more often than not perorated on his own very strong anti-Russian ideas. In a magazine, edited since November 1835 in English and French (The Portfolio, or a Collection of State Papers), he and his associates went public and disclosed Russia's malefic plans. Everything was part of an intricate conspiracy to appeal to his Russophobe audience. This historical Wikileaks revealed Russian diplomatic correspondence that exposed Emperor Nicholas I's autocratic aims, a vital threat to Europe's political balance and peace. Although the leaks were supplied by Polish sources, Urquhart's diplomatic position made The Portfolio look like an official mouthpiece of the British Foreign Office, ${ }^{5}$ further crippling the already strained relations between the governments in London and St Petersburg.

Urquhart and his adepts saved a special place in their narrative for the Black Sea and the Lower Danube, both depicted as state-of-the-art laboratories of Russian intrigue. In the marshy islands of the Danube Delta, Urquhart claimed, Russia contrived and perfected the vicious means that were to be employed for accomplishing much more grandiose political aims.

The Scotsman had two main reasons to point to the Danube Delta and signal the vital interests Russia was threatening with its tighter control over an area barely known to British statesmen or the public alike. Firstly, the Lower Danube was a symbolic border between Russia and the Ottoman Empire. Russia had reached the Danube in 1812, after annexing the eastern half of the principality of Moldavia, a territory that came to be called Bessarabia. In 1829 (through the provisions of the Treaty of Adrianople), imperial Russia took possession of the entire Danube Delta. For Urquhart, the Danube was a red line that Europe had to secure against Russia's territorial insatiability. The defence of Istanbul and of the Sublime Porte, a crucial counterweight for Europe's political stability, started in the two areas most exposed to Russia's direct pressure on both sides of the Black Sea: in the Principalities and in Circassia. ${ }^{6}$ Secondly, the economy of the Lower Danubian area was growing by leaps and bounds, fuelled by the introduction of steamship navigation on the river and the export of cheap grain crops from the Principalities. For Urquhart and his associates,

5 Charles K. Webster, 'Urquhart, Ponsonby and Palmerston,' English Historical Review 62 (1947): 331. More in Jean Marchand, 'The Portfolio de David Urquhart. Une entreprise anglaise de divulgation des documents secrets russes (1835-1845),' Revue d'histoire diplomatique 75 (1961): 136-144.

6 Charles King, 'Imagining Circassia: David Urquhart and the Making of North Caucasus Nationalism,' Russian Review 66.2 (2007): 238-255. 
the Danube was fated to become, given the rich resources of its basin, one of the most important highways of European trade. Everything was, however, at the mercy of Russia, which had no interest in allowing the economic development of territories that started to trade 'raw materials which compete with her [Russia's] own produce. ${ }^{7}$

Russian control in the Danube Delta was one of the favourite case studies of The Portfolio and of other similar Russophobe outlets popular in Western Europe. References to the commercial prospects of Danubian lands were accompanied by the exposure of Russia's malicious designs aiming to destroy its potential economic rivals. The Danube Delta was the ultimate battleground in the enduring conflict between good and evil, and Urquhart pictured himself as the augur fated to read the signs and omens of the future clash between imperial titans.

But he was not a mere soldier in a war of words. In 1835 Urquhart visited the Principalities and encouraged a more active anti-Russian political line. He supported direct economic initiatives, such as the activity of a commercial house established in Wallachia by two fellow Scotsmen, George Bell and Andrew Lockhart Anderson. ${ }^{8}$ To liberals such as Urquhart, free trade was one of the best solutions to checking Russia's advance towards the Turkish Straits: 'Let extensive depots of English wares be established on the Danube and at Trebizonde', he wrote, and 'Turkey will find in them better support than in fleets or armies'. Implanting western economic interests into two inter-imperial buffer zones across the Black Sea, in the Principalities and Circassia, was part of a clear antiRussian political programme. ${ }^{9}$

In February 1836 Russia established a quarantine service along its Danubian border. This was necessary from a sanitary perspective, given the virulent plague and cholera epidemics that had been raging in that area during the previous decade. However, local merchants readily regarded the quarantine as a gratuitous obstacle in the way of unimpeded trade and shipping both towards and from the ports of the Principalities, which were Ottoman vassal states. Foreign captains complained that their ships were arbitrarily and aggressively

7 David Urquhart, Turkey and Its Resources: Its Municipal Organisation and Free Trade; the State and Prospects of English Commerce in the East, the New Administration of Greece, Its Revenue and National Possessions (London 1833), 164.

8 E.D. Tappe, 'Bell and Anderson: a Scottish Partnership in Wallachia', Balkan Studies 12.2 (1971): 479-484; Cornelia Bodea, 'David Urquhart, the Principalities and the Romanian National Movement,' Nouvelles Études d'Histoire 7 (1985): 207-230; Paul Cernovodeanu, 'Implicațiile de ordin politic ale activității și falimentului casei de comerț "Bell \& Anderson" din București (1834-1836),' Studii și materiale de istorie modernă 12 (1998): 4-5.

9 Urquhart, Turkey and Its Resources, 174. 
approached by Russian gunboats, which, under sanitary pretences, 'boarded, visited, detained, examined and annoyed every vessel passing up the Danube.'10

At the same time, the depth of the only navigable mouth of the Danube, Sulina, gradually decreased. Russian Sulina was turned into the gateway of the Danube, which Russia could open or close according to its interests. For Russophobe circles, this was an experiment used to test international reactions. The ultimate gateway Russia aimed to master lay further south: it was the Turkish Straits.

Interpellations on Russia's quarantine followed in the British Parliament, apparently instigated by Urquhart himself, ${ }^{11}$ and several MPs denounced Russia's open aggression on British and international trade. ${ }^{12}$ British Foreign Secretary Viscount Palmerston referred to the articles of the 1815 Congress of Vienna guaranteeing free navigation to all nations. ${ }^{13}$ By July 1836 , Palmerston sent to St Petersburg an official note of protest, in which he considered that the establishment of the quarantine was the first step of a larger plan to close off the Danube for international trade. ${ }^{14}$

Urquhart visited the Principalities again in the summer of 1836 , when he probably orchestrated the attempt to overtly challenge Russia's possession of Circassia, with juridical implications for the entire Black Sea area. ${ }^{15} \mathrm{He}$ was involved in organising the voyage of the British schooner 'Vixen', which attempted to take a cargo of Wallachian salt to the seaport of Sudzhuk-Kale

$10 \quad$ 'Navigation of the Danube,' Portfolio 2 (1836): 468; Urquhart, The Mystery of the Danube. Showing How through Secret Diplomacy That River Has Been Closed, Exportation from Turkey Arrested, and the Re-Opening of the Isthmus of Suez Prevented (London 1851), 29. See also The National Archives of the United Kingdom (TNA), Foreign Office, FO 78/288, f. 80-81 (Consul R.G. Colquhoun to Viscount Palmerston, Bucharest, 30 April 1836).

11 Urquhart, The Mystery, 32; Gleason, The Genesis, 189.

12 Urquhart, The Mystery, 29; idem, Progress of Russia in the West, North and South, by Opening the Sources of Opinion and Appropriating the Channels of Wealth and Power (London 1853), 313 .

13 Hansard's Parliamentary Papers, vol. 32, House of Commons Debates, 20 April 1836, 126o1309. A modern view on the Vienna 1815 principles in Joep Schenk, 'National Interest Versus Common Interest: The Netherlands and the Liberalization of Rhine Navigation at the Congress of Vienna (1814-1815),' in: Ruud van Dijk, Samuël Kruizinga, Vincent Kuitenbrouwer and Rimko van der Maara (eds.), Shaping the International Relations of the Netherlands, 1815-200o (London 2018), 13-31.

14 Radu R. Florescu, The Struggle against Russia in the Romanian Principalities: A Problem in Anglo-Turkish Diplomacy 1821-1854, 2nd ed. (Iași 1997), 291-292.

15 G.H. Bolsover, 'Lord Ponsonby and the Eastern Question (1833-1839),' Slavonic and East European Review 13 (1934-1935): 111. 
(present-day Novorossiysk, Russia). 'Vixen' was seized by a Russian warship, ${ }^{16}$ which sparked a diplomatic conflict, but did not end, as Urquhart had hoped, in open military confrontation. As Urquhart had increasing frictions with Ambassador Ponsonby (whose instructions the Scotsman openly defied), Palmerston decided to remove him from diplomatic service. Back in London, Urquhart had two stormy interviews with Palmerston (July 1837), which convinced him that the Foreign Secretary was a traitor, probably in the pay of the Russian government. ${ }^{17}$

To Urquhart, Russia was a despotic and tyrannical power, hungry to subdue the entire civilised world, and people needed to be informed about this vast conspiracy. Perhaps minor, unimportant or even unknown to many of his naïve countrymen, the Danube was illustrative of what was coming. With regular upsurges of anti-Russian feelings and prejudices throughout the western world, it is perhaps worth historicising the genesis of Russophobia along the lines drawn by American historians John Howse Gleason, Raymond T. McNally or Albert Resis. ${ }^{18}$ In the pre-Crimean War context, the Russian threat was constructed via successful authors like Urquhart or Frenchman Astolphe-Louis-Léonor, Marquis de Custine, who played a major role in mobilising public opinion in Britain and France. In Urquhart's narrative, portraying the true character of the enemy proved convincing exactly through his references to individual case studies, such as the complications of the Danubian quarantine, where Russia's actions were detrimental to general European commercial interests.

\section{$2 \quad$ Grain and Steamship}

Urquhart's radical political views were accompanied by a coherent economic vision. He was a liberal promoting free trade who believed that economic development contributed to building a better world. By the mid-1830s Urquhart was involved in drafting a new commercial treaty between Britain and the Ottoman Porte, which eventually led to the conclusion of the Treaty of Balta Liman (1838). While such a 'colonial' agreement is still controversial among scholars interested in its economic and political outcomes, it did manage to

16 Harold N. Ingle, Nesselrode and the Russian Rapprochement with Britain, 1836-1844 (Berkeley 1976), 63-72.

17 Gleason, The Genesis, 197.

18 Gleason, The Genesis cit.; Raymond T. McNally, 'The Origins of Russophobia in France: 1812-1830,' American Slavic and East European Review 17.2 (1958): 173-189 and Albert Resis, 'Russophobia and the “Testament” of Peter the Great, 1812-1980,' Slavic Review 44.4 (1985): 681-693. 
attract to the Ottoman Empire hordes of western entrepreneurs, who started to explore the resources of the Principalities (a privileged area of the Ottoman dominions) too. Two factors were already changing the economic fate of the region - steamship navigation and the large grain harvests of the Principalities - and Urquhart readily advertised them both in his texts.

Steam navigation was introduced on the upper river in 1830, and the success of the 'Austrian Danube Steamship Company' (Erste Donau-DampfschiffahrtsGesellschaft, hereafter DDSG) made its management operate by 1836 a safe, comfortable and continuous voyage between Vienna and Istanbul on board modern Austrian steamers. In 1844, after mediation by Chancellor Metternich, the maritime section of the route was taken over by the 'Österreichischer Lloyd', and the DDSG focused on its fluvial operations. From 1846 onwards a packet of the 'Russian Steam Navigation Company' ran between Odessa and Galați, making the Moldavian port-city of Galați a growing hub on the interimperial routes connecting the Austrian, Russian and Ottoman empires. ${ }^{19}$

By the provisions of the Treaty of Adrianople, the Principalities could pursue free trade, and their agricultural production and export capacities increased exponentially once their products started to be integrated into the capitalist world economy. ${ }^{20}$ The inland ports of Brăila and Galați were the major centres of this prosperous grain trade. Soon, the two outlets were granted privileges (free port regimes) meant to further boost their economic development. If, initially, the Danube was mainly visited by Ottoman, Greek or Sardinian vessels involved in regional trading networks, by the 1840 s ships from western and northern Europe were starting to rush to the Black Sea, which had become one of the largest grain-exporting basins in the world. Hundreds of Austrian and British ships, especially after the great famine in Ireland and the abolishment of the Corn Laws in Great Britain, loaded Danubian grain at Brăila and Galați. In quantitative data, from an average number of about ten British ships per year in the late 1830s, British shipping at the Lower Danube increased to annual averages of more than $25^{\circ}$ ships in the early 1850 s. About 40 per cent of all vessels clearing the mouths of the Danube carried grain directly to British ports. ${ }^{21}$

19 Ardeleanu, 'From Vienna to Constantinople on Board the Vessels of the Austrian Danube Steam-Navigation Company (1834-1842),' Historical Yearbook 6 (2009): 187-202 and idem, International Trade, 22-28.

20 Ardeleanu, International Trade, 53-56.

21 Cernovodeanu, Beatrice Marinescu and Irina Gavrilă, 'Comerțul britanic prin Galați și Brăila între 1837-1852,' Revista de Istorie 31.4 (1978): 634; Cernovodeanu and Marinescu, 'British Trade in the Danubian Ports of Galatz and Braila between 1837 and 1853,' Journal of European Economic History 8.3 (1979): 707-741; Constantin Ap. Vacalopoulos, 'Données 
In less than two decades, the Lower Danube became a busy waterway for thousands of travellers who voyaged between Central Europe and the thriving Ottoman and Russian outlets of the Black Sea. The area had been almost completely absent from travellers' routes before the mid-1830s, and references to local goods directed even more entrepreneurs to explore the commercial prospects of Brăila and Galați. On the mental maps of businessmen in Istanbul, Izmir, Trieste or Marseille and of statesmen in Vienna, London, Paris or Turin, the Lower Danube was Europe's new California, a land of milk and honey and grain. However, the route towards the Principalities passed through the Danube Delta, an underworld with moving sands and tortuous channels, jealously guarded by a monstrous Russian Cerberus.

The story of the Lower Danube in the 1830 s is a perfect illustration of how economic and political interests rapidly emerge once an area gets connected to the routes of the world economy. Part of a contested Ottoman borderland and of a functional regional economy centred in Istanbul, Moldavia and Wallachia enjoyed a favourable constellation that challenged their role in Europe's eastern periphery. Raw materials could be freely circulated due to new liberal legislation and modern means of transportation. Merchants from Mediterranean and western deposit ports expanded their business to the Danubian outlets and included them in complex mercantile networks. Travellers visited the area and reported on its economic prospects, making even more entrepreneurs aware of its profitability. The growing businesses of Brăila and Galați made governments look closer to the Lower Danube, appoint consuls to represent their fellow tradesmen and require from them reports on the Principalities' political situation. With the Lower Danube representing an inter-imperial boundary and junction, geopolitical reasons also made their way into this equation in which economic and political interests were closely intertwined.

\section{Danubian Hindrances}

In 1829 Russia annexed the Danube Delta, and shipping towards the ports of Moldavia and Wallachia continued along the middle or Sulina branch of the river, sections of which fell completely within Russian territory. According to international agreements, Russia was responsible for keeping the channel navigable; however, during the following two decades shipping conditions in the Maritime Danube went from bad to worse. By the mid-1830s it was a widely

statistiques sur la prédominance du potentiel hellénique dans la navigation et le commerce au bas Danube (1837-1858),' Balkan Studies 21 (1980): 107-116. 
held belief among local merchants and diplomats that the Russian authorities aimed to 'strangle' Danubian shipping; thus they would limit the growth of Brăila and Galați, which threatened to become commercial rivals of Odessa and other outlets in the Ukrainian parts of the Russian Empire.

There were plenty of reasons to think that everything was part of a malefic plan. As no fortress could be erected along the Lower Danube, quarantine stations were allegedly provided with similar control and defence functions. ${ }^{22}$ The 'excessive' actions by Russia in taking sanitary precautions were doubled by an equally noticeable 'inaction' in keeping the Maritime Danube open for international navigation. The most difficult obstacle for shippers was the Sulina bar, the sandbank accumulated at the junction of river and sea, which made shipping more insecure and costly. ${ }^{23}$

Austria and Britain were the states whose economic interests seemed most harmed by Russia's Danubian policy. The Habsburg government pursued a line of cooperation with Russia, and in 1836 secured simpler shipping procedures for vessels hoisting the Austrian flag. In 1840 a special convention was signed in St Petersburg, by which Danube's navigation was declared 'completely free' and the Russian government agreed to execute all the works necessary 'to stop the silting up of the Sulina Mouth and to make this passage practicable, so as to no longer be a hindrance to navigation'. Austrian ships were to pay a toll for covering the costs of engineering and maintenance works. ${ }^{24}$ As the agreement was signed by the Russian Chancellor Nesselrode and enjoyed the backing of the Tsar, it looked like there existed the highest possible political commitment to resolve this question.

Britain, on the other hand, refused to accept the payment of a toll, and insisted on the application of the 1815 Vienna principles. Article 113 stipulated that each state 'shall maintain the necessary works in order that no obstruction shall be experienced by the navigation, ${ }^{25}$ so Russia was responsible for keeping its section of an international waterway open for the navigation of all interested nations.

22 TNA, FO 78/290, f. 138 (Consul Samuel Gardner to Palmerston, Jassy, 18 October 1836).

23 Manfred Sauer, 'Österreich und die Sulina-Frage, 1829-1854,' Mitteilungen des Österreichischen Staatsarchivs 40 (1987): 185-236 and 41 (1990): 72-137.

24 British and Foreign State Papers, 1839-1840, vol. 28 (London 1857), 1060-1063; Ștefan Stanciu and Alexandru Duță, Traités, conventions et autres documents concernant le régime de la navigation du Danube maritime (Galați 2003), 12-14. Also see 'Occupation of Sulina by Russia,' New Monthly Magazine and Humorist 91 (1851): 145-147; Vernon John Puryear, International Economics and Diplomacy in the Near East. A Study of British Commercial Policy in the Levant 1834-1853 (Stanford 1935), 144-145; Ardeleanu, Evoluția intereselor economice și politice britanice la gurile Dunării (1829-1914) (Brăila 2008), 52-53. 
The frustration of western diplomats increased in the late 1840s, when hundreds of ships loading grain at Brăila and Galați incurred great additional costs because of the low clearance depth over the Sulina bar. In London, Paris and Vienna it became clear that, despite its official commitments, Russia used its hold over the Danube Delta as a means of obstructing the prosperity of its commercial rivals upstream the Danube. With repeated references to the 1815 Vienna principles, the British Foreign Office suggested that it was perhaps advisable to have a meeting of representatives of the river-bordering states in the same manner as has been done for the Rhine and the Elbe. ${ }^{26}$

Besides trying to resolve the question through diplomatic avenues, interested parties also came up with several technical solutions. One such idea was proposed in December 1839 by merchants and ship-owners based in inland Danubian ports: they intended to establish a private company that was to purchase and operate a dredging machine and thus remove navigational obstacles along the Maritime Danube. ${ }^{27}$ Another idea vehiculated since the 1830 s was to bypass the embouchures of the Danube (and thus avoid Russian waters) by means of a canal or railway built in the narrowest area of Dobrudja. ${ }^{28}$ Austrian, Prussian, British and Ottoman engineers and diplomats tried to estimate the viability of the canal project, and Urquhart was one of the strongest adepts of its materialisation. ${ }^{29}$ Not least of all, after surveys conducted in the $1840 \mathrm{~s}$, it was proposed to open to international navigation the southern (St George) branch of the river, bordered by Russia and the Ottoman Empire.

26 Correspondence with the Russian Government Respecting the Obstructions to the Navigation of the Sulina Channel of the Danube (London 1853), 16-17 (Palmerston to John Bloomfield, London, 4 November 1850); more on this in Ardeleanu, 'Russian-British Rivalry Regarding Danube Navigation and the Origins of the Crimean War (1846-1853), Journal of Mediterranean Studies 19.2 (2010): 165-186 and idem, International Trade, 133-252.

27 Prospectus of a Company to Keep Water on the Bar at the Soulina Mouth of the Danube at a Greater Depth (TNA, FO 78/409. f. 224-227; FO 195/136, f. 535; FO 195/168, f. 473); Cernovodeanu, Relațiile comerciale româno-engleze în contextul politicii orientale a Marii Britanii (1803-1878) (Cluj-Napoca 1986), 95-96; Spiridon G. Focas, The Lower Danube River: In the Southeastern European Political and Economic Complex from Antiquity to the Conference of Belgrade of 1948 (Boulder and New York 1987), 195-197.

28 Stoica Lascu, 'Mărturii documentare privind elaborarea unor proiecte ale Canalului Dunăre - Marea Neagră,' Revista de Istorie 37.6 (1984): 534-555 and idem, 'Proiecte românești ale canalului Dunăre - Marea Neagră (1850-1940),' in: Valentin Ciorbea and Ovidiu Cupșa (eds.), Canalul Dunăre - Marea Neagră între istorie, actualitate și perspective (Constanța 2008), 21-39. 


\section{Banditry and Corruption in Russian Sulina}

Geopolitical and military calculations made the Danube Delta a strategic hold on Russia's border with the Ottoman Empire. Economically, however, the area was too eccentric to the Russian Empire's southern provinces to enjoy any major relevance within the imperial economy. But being the 'gate' of the river, the Danube Delta was vital for the interests of riparian states and of their main commercial partners. Russia's top politicians were divided in how to best use this strategic position: Count Egor Kankrin (Russia's finance minister) and some of the commercial elites in Odessa favoured the use of the quarantine to hinder trade on the Danube; other Odessite merchants were, however, interested in taking advantage of the economic opportunities provided by the new Danubian market. This latter opinion seems to have been supported by statesmen such as Nicholas I, Chancellor Nesselrode and Count Mikhail Vorontsov, Governor-General of New Russia and Bessarabia, who also valued the importance of Russia's diplomatic entente with Austria. ${ }^{30}$

As Vorontsov reported, the Russians could gain significant advantages by making good use of their Danubian gateway. ${ }^{31}$ His correspondence proves that he was keen to remove navigational hindrances, especially after concluding the July 1840 convention with Austria. In 1843, an Austrian agent, Ferdinand Mayerhofer von Grünbühel, inspected the Lower Danube and reported that the Russians had fulfilled most of their obligations, except for securing a convenient depth over the Sulina bar. ${ }^{32}$

Sulina was the smallest of Danube's three branches, carrying only about 10 per cent of its flow. It had several problems along its extremely meandering course, but at its mouth its depth permitted medium and large vessels to enter and leave the river without lightering their cargo. Seasonal works for clearing the bar were, however, needed and such activities were reported in the late eighteenth century, when the Ottoman Empire controlled the region.

After annexing the Danube Delta and moving its cordon sanitaire along the Sulina branch, Russia invested in developing the homonymous town of Sulina. Soon after its 'formal' rebirth in 1836 , it became the de facto transhipment

30 Valentin Tomuleț and Andrei Emilciuc. 'Un document inedit despre măsurile guvernului rus de contracarare a concurenței porturilor Galați și Brăila în favoarea comerțului prin portul Odessa,' Analele Universității “Dunărea de Jos" din Galați. Istorie 11 (2012): 35-55.

31 Arkhiv Kniazia Vorontsova, vol. 40 (Moscow 1895), 213 (Count M. Vorontsov to Chancellor Nesselrode, Odessa, 26 February 1837).

32 Sauer, 'Österreich,' II: 98-99. 
centre of Danubian trade. ${ }^{33}$ By the late 1840 s, Sulina was 'made of 120 houses settled on the right bank of the river without the smallest regularity'. A Russian garrison was quartered there, but it was outnumbered by new inhabitants, 'traffickers or owners of small lighters', who made the most of the busy river trade and shipping. ${ }^{34}$ Later in the 185 os a British traveller would call Sulina a 'veritable American Eden', where an entire community flourished due to the navigational problems of the vessels calling at the Danube. ${ }^{35}$

With the growth of international navigation toward the rich grain outlets of the Principalities, Russian Sulina became the haven and heaven of several hundred entrepreneurs who exploited the changing depth of the Sulina bar. Through its strategic position, Sulina became, to paraphrase Valeska Huber, a sort of mini-Suez, a global locality as an imperial relay station for merchants and ship-owners active in Danubian businesses. ${ }^{36}$ Two businesses were extremely remunerative: lighterage and piloting, and both left room for numerous complaints from seafarers, who paid huge costs for such unruly services in Russian waters. It was this state of utter arbitrariness and disorder in relation to commercial practices that deprived trade of the most elementary guarantees of security.

A large fleet of lighters was employed along the Lower Danube to carry grain from upstream ports. Sources reported the fraudulent conduct of lightermen along the Maritime Danube: many of them were Greek sailors 'who were little better than pirates' and used all sorts of devices and practices to rob the cargoes entrusted to them. ${ }^{37}$

The cost of lighterage depended on cargo, but profits were significant: the transportation of a cargo along the 100-mile long section of the Maritime Danube (from Brăila to Sulina) would cost at least a quarter of the freight from Sulina to London, a distance of more than 3,00o nautical miles. Such

33 As prophesised by Adolphus Slade, Travels in Germany and Russia, Including a Steam Voyage by the Danube and the Euxine from Vienna to Constantinople, in 1838-39 (London 1840), 198.

34 Xavier Hommaire de Hell, Voyage en Turquie et en Perse, exécuté par ordre du gouvernement français pendant les années 1846, 1847 et 1848, vol. I (Paris 1854), 214-215. The same information in John Reynell Morell, The Neighbours of Russia, and History of the Present War to the Siege of Sebastopol (London, Edinburgh and New York 1854), 78-79.

35 The name was coined by Laurence Oliphant, The Russian Shores of the Black Sea in the Autumn of 1852 with a Voyage Down the Volga, and a Tour through the Country of the Don Cossacks (Edinburgh and London 1853), 339.

36 Valeska Huber, Channelling Mobilities: Migration and Globalisation in the Suez Canal Region and Beyond, 1869-1914 (Cambridge and New York 2013).

37 John Stokes, 'The Danube and Its Trade,'Journal of the Society of Arts 38.1954 (2 May 1890): 563. 
gains attracted local Russians officials, who, consular sources further claimed, took control of lighterage and eventually monopolised it. The officer in charge at Sulina, Major Soluviov, the nephew of General Fedorov, the Governor of Bessarabia, allegedly owned no fewer than 300 lighters. Interested parties were convinced that the officers at Sulina lived entirely from the misfortune of commercial vessels ${ }^{38}$ and that they were responsible for the bad state of the Sulina passage. $^{39}$

As the British vice-consul to the Danube Delta would repeatedly state in his reports,

no parties here in the Danube have any direct interest in clearing the bar or facilitating the navigation [...]. The bar of Sulina furnishes the means of existence to the inhabitants of Sulina, by the employment of lighters, pilots, and the expenses incurred by the vessels during their detention. ${ }^{40}$

Other problems emerged in relation to the decreasing depth of the navigable channel over the Sulina bar. To cope with local navigational hazards, shipmasters were advised to employ pilots. However, the profession was not clearly regulated, and accusations abounded about 'fake pilots' who purposely wrecked the ships they steered, working in collusion with onerous lightermen who immediately offered to rescue distressed vessels.

After 1846, most of the ships that loaded grain in the Principalities were detained at the economic choke point of Sulina. Shipmasters needed to hire lighters, onto which they transferred at least part of their cargo, and reloaded it in the roadstead. It was a difficult and dangerous operation. In fact, the frequency of shipwrecks earned the local roadstead its reputation as 'a veritable cemetery of ships. ${ }^{41}$ Weather conditions prevalent in the Black Sea were blamed for

38 TNA, FO 195/136, f. 540 ('Report on the navigation of the Danube ..., drafted by Charles Cunningham, Galați, 6 February 1840); other details, according to an Austrian source, in Tudose Tatu, Cheia Dunării împărătești. Sulina cea mâlită (Galați 2013), 152-155.

39 J.D. de Bois-Robert, Nil et Danube. Souvenirs d'un touriste. Égypte, Turquie, Crimée, Provinces-Danubiennes (Paris 1855), 319.

40 Correspondence, 50 (St Vincent Lloyd to Stratford Canning, Sulina, 4 June 1853). "It is not the interest of any parties, either of the local authorities themselves, or of the inhabitants of Sulina, that the obstacles to the navigation should be removed" - ibid., 7 (Lloyd to Consul John Neale, Tulcea, 30 January 1850). See also Cernovodeanu, Relațiile, 132-133.

41 Thibault Lefebvre, Études diplomatiques et économiques sur la Valachie (Paris 1858), 358. The phrase was used in 'The Mouth of the Danube,' Freeman's Journal and Daily Commercial Advertiser, 26 July 1853. A list of vessels lost or damaged at Sulina in 1853 and 1854 - TNA, PRO 30-22/12C (Lord John Russell Papers), unnumbered (The Earl of Clarendon to Canning, London, 10 April 1855). 
many disasters. A terrible gale in 1855 provoked the wrecking of 24 commercial ships and 60 lighters, with a toll of about 300 human casualties. ${ }^{42}$

Western ship-owners and merchants accused the Russian authorities of being morally guilty for other disasters by refusing or being unable to remove the navigational obstacles from Sulina. On the one hand they alluded to the formal commitments of the Russian government to keep the Danube Delta safe for international trade and shipping, and on the other they denounced the community of corrupt Russian officials and unscrupulous transnational entrepreneurs whose unlawful and arbitrary behaviour increased natural insecurity.

The Russian government conducted several investigations into the political and military authorities of Sulina, who allegedly tolerated all these mistreatments. ${ }^{43}$ In 1847 , Nicholas I even sent to the Principalities and to Sulina a personal investigator, Radofinikin, who promised to solve all problems within a few months. ${ }^{44}$ Hardly anything changed over the course of the coming years.

One has to mention though that through its position in relation to Russia, the Ottoman Empire and the Principalities, in a completely peripheral and unhealthy environment, Sulina and the Danube Delta were a paradise for all 'entrepreneurs' interested in maximising profits, irrespective of the official regulations that were designed to establish a climate of order and legality. Such 'pirates' are, in fact, illustrative of an unregulated market in a far-off imperial periphery. Unscrupulous profiteers in both private and official positions used informal networks and illicit practices to increase their benefits. This form of economic banditry is directly related to the development of the capitalist world system and it even had its own positive outcome in the penetration of capitalism to a marshy borderland. ${ }^{45}$ But in the Russophobe environment of the time, the direct connection which could be made between the decreasing depth of the navigable channel and Russia's interests to protect its own ports was proof that Russia had no intention of removing the obstacles that hindered commercial navigation along the Maritime Danube.

42 'The Sulina Mouth of the Danube,' Household Words, a Weekly Journal, no. 307 (9 February 1856): 75-76; Charles Hartley, 'Description of the Delta of the Danube and of Works Recently Executed at the Sulina Mouth,' Minutes of the Proceedings of the Institution of Civil Engineers 21 (1862): 291.

43 Sauer, 'Österreich,' II: 102.

44 The Education of a Russian Statesman: The Memoirs of Nicholas Karlovich Giers, edited by Charles and Barbara Jelavich (Berkeley 1962), 221.

45 Thomas W. Gallant, 'Brigandage, Piracy, Capitalism, and State-Formation: Transnational Crime from a Historical World-Systems Perspective,' in: Josiah McC. Heyman (ed.), States and Illegal Practices (Oxford and New York 1999), 25-62. 
'The whole and chief difficulty of the navigation of the Danube' was, according to a mid-nineteenth century account, 'that at its mouth the water is not always of a sufficient depth to admit large vessels' without lightering part of their cargo. ${ }^{46}$

Reduced to only about 11 feet, frequently not more than 9 feet and sometimes measuring only 7 feet, from a reported depth of 15 feet in good, old Ottoman times, physical impediments resulted in considerable financial injuries for international shipping. This came from both the expense of transhipping the cargoes into lighters and from the dangers to which vessels and cargoes were exposed. The growth of British navigation after 1846 determined a proportional increase in the number of complaints regarding the state of the Sulina bar, which was causing losses amounting to at least $£ 100,000$ a year. The most prejudiced, on account of the superior size and draught of their vessels, were the British and Austrian ship-owners, whereas the main beneficiaries were the merchants of Odessa: additional expenses, determined by the cost of lighterage and the higher rates of insurance, increased the price of Danubian grain enough to place it on disadvantageous terms in comparison with that exported from the Russian Empire's southern ports. ${ }^{47}$

When forwarded to the Russian government in St Petersburg, these complaints received positive replies, with Chancellor Nesselrode giving formal assurances that local authorities had clear orders to remove all obstacles. However, 'all that was required could not be effected as speedily as we [the British] seemed to expect. 48 In the early 1850 os a British manufactured steam dredging machine worked at the Sulina mouth to clear the passageway, but its activity rendered insufficient results, especially as the Russians lacked qualified personnel to properly operate the machine.

Prior to the Crimean War, the Sulina bar controversy played an important part in the diplomatic conflict between the British and Russian cabinets. Viscount Palmerston sent repeated dispatches to St Petersburg, referring to the Russian government's juridical responsibility, according to the provisions established at the Congress of Vienna, to guarantee the freedom of navigation on the Danube. ${ }^{49}$ In the autumn of 1851 , diplomatic relations were strained

46 'Occupation of Sulina': 145 .

47 Ibid., 145-146.

48 Correspondence, 5 (Bloomfield to Palmerston, St Petersburg, 30 October 1849).

49 Ibid., 14 (Palmerston to Bloomfield, London, 4 October 1850). 
enough to make Ambassador George Hamilton Seymour in St Petersburg consider that it was more appropriate not to act upon Palmerston's instructions, as 'fresh remonstrances' generated by British 'mistrust' of Russia's intentions 'would only produce an angry reply from the Russian Chancellier. 50

As mentioned before, diplomatic circles in St Petersburg seem to have had real intentions to solve the Sulina Question. In April 1852, Nesselrode bitterly referred to the fact that the dredger no longer worked at Sulina, ordering its immediate return to the mouth of the Danube, so as not to 'gravely compromise ourselves in front of Austria and England. ${ }^{51}$ However, the seemingly good intentions of Russia's central authorities were subject to the indifference or adverse priorities of the local circles in Sulina.

British economic and political circles were not the only ones discontented with the obstructions from the Maritime Danube. The Austrian, French and Sardinian vice-consuls reported in the same vein. In 1850, Russia's failure to respect its obligation to clear the Sulina mouth, as assumed by the $1840 \mathrm{St}$ Petersburg Convention, led to Austrian plans to open a new channel of communication between the Danube and the Black Sea. ${ }^{52}$ The French press reported on the renewal of the convention, which Austria conditioned on the immediate clearance of Sulina and the removal of the quarantine and of the other obstacles that limited free navigation of international ships; ${ }^{53}$ however, the Austrian government resumed its negotiations with the Ottomans for the prospected canal across Dobrudja. ${ }^{54}$ Russia and Austria gave the 1840 Convention a one-year respite, but it still did not reach the purpose desired in Vienna, as shipping conditions along the Maritime Danube went from bad to worse. 55

$50 \quad$ Ibid., 39 (G.H. Seymour to Palmerston, St Petersburg, 20 October 1851).

51 Arkhiv Kniazia Vorontsova, vol. 40, 433-434 (Nesselrode to Vorontsov, St Petersburg, 17 April 1852).

52 Dimitrie Bodin, Documente privitoare la legăturile economice dintre Principatele Române și Regatul Sardiniei (Bucharest 1941), 218 (Stefano Berzolese to Massimo d'Azeglio, Galați, 17 October 1850).

53 'France. Paris, 7 Juillet,' Journal de débats politiques et littéraires, Paris, 8 July 1850.

54 'France. Paris, 19 Juillet,' ibid., Paris, 20 July 1850.

55 Henry Hajnal, The Danube. Its Historical, Political and Economic Importance (The Hague 1920), 63; also in Carey Goodman, 'Austria's Danubian Diplomacy during the Crimean War,' in: June K. Burton and Carolyn W. White (eds.), Essays in European History: Selected from the Annual Meetings of the Southern Historical Association, 1988-1989, vol. II (Lanham 1996), 213 . 

the Danube

Returning to Urquhart, from the late 1830 s he directed his anger in relation to Danubian navigation both at Russia and Palmerston's pacific foreign policy. In 1851, Urquhart's new book The Mystery of the Danube was a renewed revelation of the conspiracy orchestrated from St Petersburg. Though no man is a prophet in his own land, Urquhart's accusations were not the mere figment of an alienated Russophobe mind, and by 1853 many people concurred with his views.

In July 1853, Russian troops occupied the Principalities, an episode that later developed into the Crimean War. As with all previous Russian military occupations (in 1828-1834 and 1848-1851), this came with direct consequences for the flourishing trade of Moldavia and Wallachia, and for European interests in the area. By 1853, the commerce between Britain and the Principalities had grown to such a point that the provinces were supplying about 600,000 quarters of grain a year, i.e. more grain than any other Ottoman province except for Egypt. Also, one third of all ships calling at the Danubian ports were either British or Britain bound. ${ }^{56}$

At the same time, another of Urquhart's long due predictions seemed to come true: with only about 7 feet of water over the Sulina bar, Danube navigation was virtually closed. More than 30 vessels (among them fifteen Austrian and eleven British) were blocked at Sulina in July 1853, unable to sail over the bar into open sea. Dozens of other vessels bound up in the river waited in the roadstead. ${ }^{57}$ The Earl of Clarendon, the British Foreign Secretary, instructed Ambassador Seymour in St Petersburg to call the attention of Count Nesselrode to the great loss and inconvenience occasioned by the existing state of things to commerce in general, and especially to that of England', on account of the obstructions at Sulina. ${ }^{58}$ A couple of days later, the question was raised in the House of Commons by Henry Liddell, an interpellation to which Palmerston, as Home Secretary, gave a very elaborate reply. He referred to the weather conditions which temporarily amplified the obstructions, as well as Sulina's historical context where

for a great many years past, Her Majesty's Government have had great reason to complain of the neglect of the Government of Russia to perform

56 Florescu, The Struggle, 287-289; Cernovodeanu, Marinescu, Gavrilă, 'Comerțul britanic': $631-633$.

57 TNA, FO 78/948, f. 271 (Cunningham to Clarendon, Galați, 30 July 1853).

$5^{8}$ Correspondence, 48 (Clarendon to Seymour, London, 5 July 1853). 
those duties which belong to it as the possessor of the territory where the delta of the Danube is situated, to clear and maintain clear that particular branch. ${ }^{59}$

On 21 July, Lord Dudley Stuart resumed the interpellation, inquiring whether the British authorities would demand compensation from Russia for merchant losses inflicted by the culpable neglect of the Russian government and demanding access to the correspondence on the subject. ${ }^{60}$

The publication of British-Russian confidential diplomatic dispatches added fuel to the fire, as the volume seemed to fully prove Russia's dishonesty in improving the conditions prevalent at the Maritime Danube. Fragments from the English blue book were scattered throughout the European press. The protests of the diplomatic and consular agents were doubled by overt criticism in the daily press, as the steamers plying between Galați and Istanbul remained blocked at Sulina. It was no longer only a mercantile issue since it affected a very busy transport route in southeastern Europe. As one newspaper put it, the mud and sand from the Maritime Danube had leagued with the czar and thrown up a rampart which gives him as effectual control over the stranded vessels as if he had them in actual possession' ${ }^{61}$

When Irishman Patrick O'Brien visited Sulina in September 1853, it was not an attractive sight for the hundreds of voyagers aboard the Austrian steamers plying from Istanbul to the Danubian port-cities of Galați and Brăila:

I counted more than two hundred vessels of different sizes at anchor in the river. Some had been there for three months, unable to get over the bar! almost every attempt to get to sea had proved fatal since the beginning of the month of June; and all efforts to cut a channel through the bar, appear to have been abandoned.

For British adepts, removing such obstacles seemed simple enough. With a little good will on all sides, continued O'Brien, 'nothing would be easier than to keep a passage open through the bar, of from fourteen to sixteen feet deep', through simple hydraulic works. ${ }^{62}$

59 Hansard's Parliamentary Papers, vol. 128 (London 1853), House of Commons Debates, 7 July $1853,1373^{-1375}$.

$60 \quad$ Ibid., vol. 129 (London 1853), House of Commons Debates, 21 July 1853, 543-544.

61 'The Trap in the Danube - Who Made It?', Freeman's Journal and Daily Commercial Advertiser, Dublin, 7 July 1853 .

62 Patrick O'Brien, Journal of a Residence in the Danubian Principalities in the Autumn and Winter of 1853 (London 1854), 8-10. 
In fact, the Irish agent stated things that many foreign merchants and diplomats active in the Danubian ports kept repeating for more than two decades: the navigable depth over the Sulina bar was gradually decreasing, and the Russian authorities in control of the Danube Delta had merely pretended to remove the obstacles that impeded proper navigation.

\section{$7 \quad$ Conclusions}

The increasing British focus on the Lower Danube region was related to the activity of two very active British vice-consuls at Galați and Brăila. Charles Cunningham was based at Galați between 1836 and 1860 and usually filled his reports with diatribes against the Russians. As he was also employed by western insurance companies such as Lloyd's, he often travelled to the Danube Delta and reported on the causes of shipping accidents. Cunningham insisted in his reports (some published in the British press) on the idea that maintaining a navigable depth at Sulina was a cheap and undemanding technical accomplishment. Russian ill-will had to be blamed for the huge losses incurred by foreign merchants. Similar reports came from St Vincent Lloyd, the viceconsul in Brăila, whom in the late 1840 s Palmerston moved closer to the Danube Delta, in the Ottoman town of Tulcea and then to the Russian port of Ismail, as the Russians did not accept his being quartered at Sulina. He reported on the anarchy which ruled in the Danube Delta, a situation that had become of visible material harm to British and international economic interests. Palmerston was gradually converted to this view, as Russia's lack of interest in improving Danube navigation could easily be construed as a deliberate action meant to disfavour an economic rival.

A recent paper focuses on the role of British diplomatic staff and merchants in the Principalities as an 'epistemic community' who exerted a path-dependent influence at a critical juncture (the 1856 Paris Congress). In their correspondence, merchants stressed specific epistemic claims to illustrate Russia's wilful neglect by referring to the good condition of the Sulina bar during Ottoman times. Their language demonstrated a moral indignation at Russia, which arose from the 'injustice of a service paid for but not delivered - a violation of commercial codes everywhere. ${ }^{63}$ Furthermore, control and exploitation of

63 Yuan (Joanne) Yao, 'Standing at the Confluence: Institutional Emergence and the Case of the European Commission of the Danube,' working paper, ECPR General Conference Glasgow September 2014, online at https://ecpr.eu/Filestore/PaperProposal/9o2daaia -b2a2-4b78-adb4-36aa663c9co1.pdf (visited on 14 March 2018); also in eadem, Constructing 
nature developed at that time as a 'standard of civilisation', allowing states to claim membership in a civilised European society. It would have both demonstrated the exercise of internal territorial control and respect for international agreements with other actors, both of which Russia disgracefully failed to do. ${ }^{64}$

This chapter has also touched upon the conspiracy-security nexus in historicising international relations. ${ }^{65}$ Urquhart had all the 'qualities' to embark upon the task of constructing a credible conspiracy. His megalomaniac character and paranoid style were doubled by the semi-official documents that he kept leaking and by the compelling force of his literature. His success as a publicist came from mastering the new means of information in the form of political journals and by feeding his thirsty audience with a master narrative that identified clear heroes and villains. Conspiracies are about dark forces operating behind the scenes, and it was hardly difficult to portray the Russians as the civilised world's greatest enemy. The Danube was a convenient example to showcase how much Russia's actions affected international trade and shipping.

According to information from Russian sources, twenty shipwrecks were recorded in the Russian section of the Maritime Danube in $185^{0}$ - three on the river and seventeen at the Sulina mouth. 42 ships were wrecked in 1851 (22 on the river and twenty at the Sulina mouth), 25 in 1853 and eight in 1854, when, due to the war, only 71 vessels entered the Danube. ${ }^{66}$ With such staggering accident rates - caused by the insufficient depth of the navigable channel, adverse weather conditions and human error or failure of ship equipment - shipping on the Maritime Danube was increasingly insecure and costly. Skippers, however, continued to call at the inland Danubian outlets where grain prices allowed them to make highly profitable transactions. The hydrographical conditions of an unengineered river, tortuous and, at several sites, shallow, were exacerbated by Russia's alleged inaction in removing or minimising the sources of uncertainty. The officials appointed to secure a navigable passage at Sulina indulged themselves, colluding with an entire community of transnational 'pirates' in 'milking' ship-owners of a large part of their profit. Moral outrage against this

the Ideal River: the 19th Century Origins of the First International Organizations, PhD dissertation, London School of Economics and Political Science (London 2016).

64 Yao, "Conquest from Barbarism": The Danube Commission, International Order and the Control of Nature as a Standard of Civilization,' European Journal of International Relations 25.2 (2019): 335-359.

65 Beatrice de Graaf and Cornel Zwierlein, 'Historicizing Security - Entering the Conspiracy Dispositive,' Historical Social Research/Historische Sozialforschung 38.1 (2013): 46-64.

66 Emilciuc, 'The Trade of Galați and Brăila in the Reports of Russian Officials from Sulina Quarantine Station,' in: Ardeleanu and Andreas Lyberatos (eds.), Port Cities of the Western Black Sea Coast and the Danube. Economic and Social Development in the Long Nineteenth Century (Corfu 2016), 89-9o. 
state of affairs was conveyed from mercantile circles to diplomatic ones, and the Sulina Question had shipping insecurity at its core. This insecurity impacted not only the gains of traders and skippers in the inland ports of Brăila and Galați, but also the replenishment of Western Europe's grain storehouses and thus the continent's food security. With the Danube as one of Europe's largest international rivers, shipping insecurity and commercial unpredictability were translated into inter-imperial political disputes, inflated by the Russophobe views perorated by Urquhart and his adepts.

At the outbreak of the crisis that was to turn into what historians call the Crimean War, the Sulina Question was one of the major controversies separating Russia and western cabinets. While it was not the cause for the outbreak of the conflict, by late 1853 'the river was nonetheless uppermost in the minds of Europe's statesmen, diplomats, and military planners, ${ }^{67}$ who were determined to remove from the Maritime Danube 'the moral and material obstacles' which 'prejudices the commerce of all nations'. ${ }^{68}$ Doing this would make European diplomats look for innovative solutions, which included the creation of river institutions on the model of the Central Commission for the Navigation of the Rhine, the world's first international organisation. The next chapter will explain how diverging imperial interests became balanced before, during and in the aftermath of the 1856 Paris Peace Congress and why the establishment of the Commission was an innovation in international law.

67 Richard Frucht, 'War, Peace, and Internationality: The Danube, 1789-1916,' in Apostolos E. Vacalopoulos, Constantinos D. Svolopoulos and Béla K. Király (eds.), Southeast European Maritime Commerce and Naval Policies from the Mid-Eighteenth Century to 1914 (Boulder and Highland Lakes 1988), 85 .

Heinrich F. Geffcken, La Question du Danube (Berlin 1883), 8-9. 